Acta Sci. Pol. Technol. Aliment. 18(4) 2019, 349-359

pISSN 1644-0730

eISSN 1898-9594

http://dx.doi.org/10.17306/J.AFS.2019.0645

ORIGINAL PAPER

Received: 4.03.2019

Accepted: 6.09.2019

\title{
THE EFFECTS OF CAMEL MILK POWDER ON THE STABILITY AND QUALITY PROPERTIES OF PROCESSED CHEESE SAUCE
}

\author{
Marwa Mohamed Desouky ${ }^{1 \bowtie}$, Heba Hassan Salama², Samah Mosbah El-Sayed ${ }^{2}$ \\ ${ }^{1}$ Dairy Unit, Breeding Department, Animal Production Division, Desert Research Center \\ 1 Mathaf El-Matariya St., 1753 Cairo, Egypt Egypt \\ ${ }^{2}$ Dairy Department, Food Industry and Nutrition Research Division, National Research Centre \\ 33 El-Buhouth St. (former El-Tahrir St.) 12622 Dokki, Giza, Egypt
}

\begin{abstract}
Background. Camel milk contains all the essential nutrients as cow's milk, and has potential beneficial nutritive properties. The drying process has a little effect on the surface composition of milk powders. The use of camel milk powder in the manufacture of processed cheese could produce a product with special functional properties.

Material and methods. The effects of adding different concentrations of camel milk powder (CMP; ranging from 5 to $15 \%$ ) as a new functional source to replace the cheese base in the manufacture of processed cheese sauces with highly acceptable quality and sensory properties were investigated.

Results. All treatments varied significantly $(p \leq 0.05)$ in their properties depending on the percentage of CMP added and the storage period $\left(6 \pm 0.5^{\circ} \mathrm{C}\right.$ for 30 days $)$. The $\mathrm{pH}$, meltability, oil separation, viscosity and sensory properties of cheese sauce were measured during the storage period. Also, the chemical composition of the freshly prepared cheese sauces was examined. The moisture and total solids content decreased and increased significantly $(p \leq 0.05)$, in line with an increase of CMP in the cheese base formula, while the fat separation decreased with an increase in the percentage of camel milk powder added to the blends. The oil separation and meltability values increased $(p \leq 0.05)$ in all treatments, even in the control, throughout the storage period. Among treatments, the cheese sauce containing 15\% CMP (T3) was characterized by higher viscosity values during the examined time of shearing and presented higher upward shifting of the flow curve, as compared with the other treatments, either fresh or during storage. All cheese treatments were more accepted by the panelists and rated above average, particularly with an increase in the ratio of CMP added of $10 \%$. Conclusion. The addition of CMP improved $(p \leq 0.05)$ the quality attributes of cheese sauces and could be considered as a new different source to substitute cheeses used in base blends of processed cheese.
\end{abstract}

Keywords: camel milk powder, processed cheese sauces, chemical composition, physicochemical properties, viscosity, sensory properties

\section{INTRODUCTION}

Camel milk contains all the same essential nutrients as cow's milk but differs from it in the absence of $\beta$-lactoglobulin and high protective whey proteins, such as lactoferrin (ten times higher than in cow's milk). Also, camel milk has better quantities of vitamin $\mathrm{C}$, ash, sodium, potassium, phosphorus, zinc, iron and manganese than cow's milk (Hashim et al., 2009). A previous study suggested the use of camel milk in the production of 
infant formula (Moslehishad et al., 2013). Furthermore, camel milk exhibited anti-viral and anti-bacterial properties which are effective against pathogens, and had a high immunoglobulin content, which confers its high antimicrobial properties (Korashy et al., 2012). Camel milk has potential beneficial properties, such as anti-carcinogenic (Sharma and Singh, 2014), antihypertensive (Quan et al., 2008) and anti-diabetic ones (Gul et al., 2015).

Spray drying is a method of producing a dry powder from a liquid or slurry by rapidly drying with a hot gas. This is the preferred method of drying of many thermally sensitive materials, such as foods and pharmaceuticals. Spray drying is the most used commercial method for drying milk (characterized by a very short time of heat contact) with a relatively low cost and high rate of evaporation that gives a product of high quality with a consistent particle size distribution (Mujumdar, 2007). The principle of spray drying is to remove the water from the milk concentrate as fast and at as low a temperature as possible to minimize heat damage to the milk solids.

A dry product is highly desirable since it possesses a long shelf life, requires relatively low transportation costs and has an extended storage ability (whole milk powder has a shelf life of 12 months and skim milk powder in excess of 2 years) when stored under suitable moisture and temperature conditions (Thomas et al., 2004). The main reason for the manufacture of camel milk powder is to extend shelf life without losing nutritive value and to simplify storage and usage, especially in desert areas. In addition, its application in dairy products can be distributed over a wide area, which is highly desirable.

During the production of milk powder, milk components are assumed to be uniformly distributed in the concentrate being dried. These components are redistributed in the drying droplets, and the powder surface composition is significantly different from that of the bulk (Kim et al., 2005). The surface composition of milk powders is determined to a large extent during the spray drying process; the drying process has no or little effect on the surface composition of milk powders. This means that the main redistribution of milk components takes place mainly during the spray drying process (Kim et al., 2008).

Processed cheese sauces are novel cheese products not well established in the Egyptian market despite being extensively used in the food sectors in equipped and pre-prepared meals as an ingredient or a desirable appetizer. They are becoming more widely popular because of their simple use and long shelf-life. Also, it is considered a uniquely important source of calcium in dairy foodstuffs in a stable diet and an important source of protein and other nutrients. The food manufacturing industry is motivated to produce lower prices, good health and suitable products as well as meet consumer requirements (Mohamed et al., 2011).

Cheese sauces can come in several forms, including frozen, semi-liquid, shelf-stable or as dry mixtures. Also, there are no principles of legal characteristics for cheese sauce. Nowadays, manufacturers use a lot of varieties of cheese ingredients such as natural cheese, cheese powder and processed cheeses, and other dried ingredients can be used in the formula (Childs et al., 2009). The texture of a cheese sauce is improved by industrial texturizing ingredients such as xanthan gum or other mixed hydrocolloids. These components are useful in the control of viscosity, suspension of particles, emulsification, prevention of separation and the offering of qualities such as body and stability (Solowiej et al., 2010).

There is a trial to modify and develop the nutritional value of processed cheese to obey consumer needs. The use of camel milk powder in the manufacture of processed cheese could present a product with special functional properties. To the best of our knowledge, no studies have previously considered the drying technique for camel milk in the manufacture of processed cheese sauce. The broad objective of the study was to determine the suitability of adding different levels of camel milk powder to enhance the quality attributes of processed cheese sauce with an acceptable shelf-life during storage and functional and health properties.

\section{MATERIALS AND METHODS}

\section{Materials}

Fresh, raw camel milk was collected from a herd of camels belonging to the Desert Research Center in the North Western Coastal area of the Matrouh Governorate, Egypt. The milk was immediately preserved and stored under refrigerated conditions until use. Bulk camel milk samples contained $12.52 \pm 0.85 \%$ total solids, $3.82 \pm 0.07 \%$ fat, $3.54 \pm 0.06 \%$ total protein, 
$4.32 \pm 0.10 \%$ carbohydrates (by the difference), 0.84 $\pm 0.01 \%$ ash and a $\mathrm{pH}$ of $6.6 \pm 0.54$. Cheddar cheese was obtained from a local market, Cairo, Egypt. Corn starch was obtained from the starch and glucose company, Cairo, Egypt. Commercial fine grade salt was obtained from El-Nasr saltines Co. Alexandria, Egypt. Emulsifying salts were obtained from JOHA BK Ladenburg Corp., GmbH, Ladenburg, Germany.

\section{Methods}

Preparation of camel milk powder by spray drying. The milk samples were transferred to a spray drier model co-current Mini Spray Dryer B-290 (BÜCHI, Flawil, Switzerland). The drying conditions were $180^{\circ} \mathrm{C}$, a flow rate of $20 \mathrm{ml} / \mathrm{min}$, and a pressure of 1.5 bars. The dried milk samples were immediately removed from the spray dryer, cooled, weighed and packaged in stainless steel containers. The yield was calculated as follows: yield, $\%=$ weight of milk pow$\mathrm{der} /$ weight of liquid milk $\times 100$. The composition of whole camel milk powder was as follows: 89.52 $\pm 4.07 \%$ total solids, $29.20 \pm 2.85 \%$ fat, $20.72 \pm 1.64 \%$ total protein, $32.52 \pm 2.10 \%$ carbohydrates (by the difference), $6.64 \pm 0.87 \%$ ash and $6.30 \pm 0.74 \mathrm{pH}$.

\section{Preparation of cheese sauce manufacture using} camel milk powder. The cheese sauce formulation used in this study was described by Li et al. (2004). To prepare the cheese sauce, water was heated to $82-93^{\circ} \mathrm{C}$ in a kettle. Disodium phosphate and sodium citrate were added with agitation, followed by the chopped cheese. Camel milk powder was added at different ratios: $5 \%, 10 \%$ and $15 \%$ for $\mathrm{T} 1, \mathrm{~T} 2$ and $\mathrm{T} 3$, respectively, while the control treatment formula was without camel milk powder. The emulsifier was added for all blends at a ratio of $0.2 \%$. High shear mixing continued until the cheese was entirely melted. Starch and salt were then added to the blend under high agitation. This process took no more than 5 minutes and resulted in a smooth sauce with a creamy consistency. The sauce was then placed into stainless steel containers and stored overnight at $7^{\circ} \mathrm{C}$ for processing the next day. The sauce was heated in a kettle to about $100^{\circ} \mathrm{C}$ with agitation until it was uniformly melted without chunky particles. Cheddar cheese was substituted with camel milk powder at different ratios: $0 \%, 5 \%, 10 \%$ and $15 \%$. All treatments were poured into glass jars
(50 g) and capped directly after filling. The resultant cheese sauces were cooled at room temperature before storage then stored in a refrigerator (at $6 \pm 0.5^{\circ} \mathrm{C}$ ) till the end of the storage period. Samples of the cheese sauce were analyzed for chemical and physical properties, and sensory attributes were determined when fresh and during storage. The experiment was carried out in triplicate. Data were reported as the average of three replicates.

Chemical analysis. The cheese sauce samples were tested for moisture, fat and ash contents as mentioned by AOAC (2007). Total nitrogen (TN) content was measured using the semi-micro Kjeldahl method according to the method described by Ling (1963).

Physicochemical properties. Values of $\mathrm{pH}$ were measured using the electric HANNA instrument, $\mathrm{pH}$ 213 microprocessor $\mathrm{pH}$ meters by inserting the $\mathrm{pH}$ combined glass electrode (Electric Instruments limited) directly into the sample. Values of $\mathrm{pH}$ were reported to the nearest 0.01 units.

Physical properties. The oil separation index (OSI) of the cheese sauces was determined as described by Thomas (1973). Meltability of the cheese sauce samples was determined according to the method designed by Olson and Price (1958) as modified by Savello et al. (1989). The viscosity of the cheese sauce samples was measured according to Viturawong et al. (2008) using a Brookfield viscometer (LV-DT H05390, Brookfield Engineering Lab., Inc., Stoughton, MA, spindleno. S93).

Sensory evaluation. Sensory evaluation was carried out according to the scheme of Meyer (1973). The evaluation was done when fresh and during storage up until 4 weeks in a refrigerator $\left(6 \pm 0.5^{\circ} \mathrm{C}\right)$ by regular scoring panel members of the Animal Production Division, Desert Research Center and Dairy Department, National Research Center (NRC).

Statistical analyses. All experiments and analysis were done in triplicate. Statistical analyses were carried out using the General Linear Models procedure of the SPSS 16.0 Syntax Reference Guide (SPSS, 2007). The results were expressed as least square means with standard errors of the mean. Statistically different 
groups were determined by the LSD (least significant difference) test $(p \leq 0.05)$.

\section{RESULTS AND DISCUSSION}

\section{Chemical composition}

The chemical composition of the processed cheese sauce manufactured by adding different concentrations $(0 \%, 5 \%, 10 \%$ and $15 \%)$ of camel milk powder to the base formula is presented in Table 1 . The moisture content of the processed cheese sauce ranged from 64.92 to $60.72 \%$ in all treatments, including the control. The moisture content decreased significantly $(p \leq 0.05)$ with an increase in camel milk powder in the base formula. This decrease in moisture content was reflected in an increase in the total solids. The highest total solids were noted with T3 (15\% camel milk powder) while the lowest total solids percentage was in the control treatment. The ash content in the processed cheese sauce also presented in Table 1 decreased to record the lowest value of $3.43 \%$ in T3 $(15 \%$ camel milk powder), which may be due to the higher amount of cheddar cheese during substitution with camel milk powder at different ratios: $0 \%, 5 \%, 10 \%$ and $15 \%$.

The cheddar cheese was high in ash and salt compared with the camel milk powder. The data of ash content is in agreement with Hassan et al. (2007), who noted that the ash content decreased with an increase in the substitution ratio of soybean flour or flaxseed. The protein contents of the processed cheese sauce treatments were $8.70 \%, 8.61 \%, 8.89 \%$ and $9.17 \%$ in the control and treatments with camel milk powder in ratios of $5 \%, 10 \%$ and $15 \%$, respectively. These results show that the control treatment had the lowest protein values among all substitutions of the cheese base in the processed cheese sauce formula with camel milk powder leading to higher protein values in treatments. The higher values of protein in treatments with a cheese base substitution of camel milk are due to the differences in protein content, since it is higher in camel milk powder than in the cheese base. The data regarding protein content are also in agreement with Hassan et al. (2007). As presented in Table 1, the percentage of fat decreased with an increase in the substitution of the cheese base with camel milk powder to record the highest fat content in the control treatment $(15 \%)$, while the lowest fat was recorded with T3 (12\%), which had a substitution of $15 \%$ camel milk powder from the cheese base. F/DM ratios were related to that of fat and moisture contents in the processed cheese sauce treatments. Therefore, the F/DM ratios showed a value ranging from 42.76 to 30.55 .

The data presented in Table 2 refers to the moisture and total solids content of the processed cheese sauce manufactured by different ratios of camel milk powder, fresh and during the storage period. The moisture when fresh was higher in the control treatment and decreased in the treatment with an increase in the substitution of cheddar cheese with camel milk powder at different ratios from $5 \%$ to $15 \%$. This lower moisture content in the treatments was due to a lower moisture content in camel milk powder when compared with cheddar cheese and also the high level of whey protein in camel milk powder (Kappeler et al., 2016). During

Table 1. Chemical composition of fresh processed cheese sauce manufactured using different ratios of camel milk powder

\begin{tabular}{ccccccc}
\hline \multirow{2}{*}{$\begin{array}{c}\text { Treat- } \\
\text { ments }\end{array}$} & \multicolumn{5}{c}{ Chemical composition } \\
\cline { 2 - 7 } & moisture & ash & protein & fat & T.S & F/DM \\
\hline Control & $64.92^{\mathrm{A}} \pm 3.71$ & $4.32^{\mathrm{A}} \pm 0.81$ & $8.70^{\mathrm{B}} \pm 1.08$ & $15.0^{\mathrm{A}} \pm 1.20$ & $35.08^{\mathrm{C}} \pm 2.16$ & $42.76^{\mathrm{A}} \pm 2.51$ \\
$\mathrm{~T} 1$ & $64.30^{\mathrm{A}} \pm 3.22$ & $4.26^{\mathrm{AB}} \pm 0.79$ & $8.61^{\mathrm{B}} \pm 0.96$ & $14.5^{\mathrm{AB}} \pm 1.17$ & $35.71^{\mathrm{C}} \pm 2.19$ & $40.60^{\mathrm{B}} \pm 2.37$ \\
$\mathrm{~T} 2$ & $62.99^{\mathrm{B}} \pm 3.14$ & $3.94^{\mathrm{B}} \pm 0.65$ & $8.89^{\mathrm{AB}} \pm 0.99$ & $14.0^{\mathrm{B}} \pm 1.16$ & $37.01^{\mathrm{B}} \pm 2.23$ & $37.83^{\mathrm{C}} \pm 2.19$ \\
$\mathrm{~T} 3$ & $60.72^{\mathrm{C}} \pm 3.05$ & $3.43^{\mathrm{B}} \pm 0.62$ & $9.17^{\mathrm{A}} \pm 1.14$ & $12.0^{\mathrm{C}} \pm 1.11$ & $39.28^{\mathrm{A}} \pm 2.27$ & $30.55^{\mathrm{D}} \pm 2.05$ \\
\hline
\end{tabular}

Control - processed cheese sauce made without camel milk powder (CMP), T1 - 5\% CMP, T2 - 10\% CMP, T3 - 15\% CMP. The means with the different capital (A-D) superscript letters within the same column indicate significant $(P \leq 0.05)$ differences between treatments for concentrations of camel milk powder. 
Desouky, M. M., Salama, H. H., El-Sayed, S. M. (2019). The effects of camel milk powder on the stability and quality properties of processed cheese sauce. Acta Sci. Pol. Technol. Aliment., 18(4), 349-359. http://dx.doi.org/10.17306/J.AFS.2019.0645

Table 2. Moisture and total solids content of processed cheese sauce manufactured using different ratios of camel milk powder fresh and during storage period

\begin{tabular}{|c|c|c|c|c|c|c|c|c|}
\hline \multirow{3}{*}{ Treatment } & \multicolumn{4}{|c|}{ Moisture, \% } & \multicolumn{4}{|c|}{ Total solids, $\%$} \\
\hline & \multicolumn{8}{|c|}{ storage period, days } \\
\hline & fresh & 10 & 20 & 30 & fresh & 10 & 20 & 30 \\
\hline Control & $\begin{array}{l}64.92^{\mathrm{aA}} \\
\pm 3.25\end{array}$ & $\begin{array}{l}63.46^{\mathrm{bB}} \\
\pm 3.09\end{array}$ & $\begin{array}{l}64.31^{\mathrm{abAB}} \\
\pm 3.20\end{array}$ & $\begin{array}{l}65.04^{\mathrm{aA}} \\
\pm 3.37\end{array}$ & $\begin{array}{l}35.08^{\mathrm{bcE}} \\
\pm 2.17\end{array}$ & $\begin{array}{l}36.54^{\mathrm{aFG}} \\
\pm 2.24\end{array}$ & $\begin{array}{l}35.69^{\mathrm{bE}} \\
\pm 2.18\end{array}$ & $\begin{array}{l}34.97^{\mathrm{cF}} \\
\pm 2.11\end{array}$ \\
\hline $\mathrm{T} 1$ & $\begin{array}{l}64.30^{\mathrm{aAB}} \\
\pm 3.18\end{array}$ & $\begin{array}{l}63.86^{\mathrm{bB}} \\
\pm 2.82\end{array}$ & $\begin{array}{l}63.52^{\mathrm{bBC}} \\
\pm 3.11\end{array}$ & $\begin{array}{l}63.29^{\mathrm{bC}} \\
\pm 3.08\end{array}$ & $\begin{array}{l}35.71^{\mathrm{bE}} \\
\pm 2.23\end{array}$ & $\begin{array}{l}36.12^{\mathrm{abGE}} \\
\pm 2.21\end{array}$ & $\begin{array}{l}36.49^{\mathrm{aFG}} \\
\pm 2.20\end{array}$ & $\begin{array}{l}36.72^{\mathrm{aF}} \\
\pm 2.23\end{array}$ \\
\hline $\mathrm{T} 2$ & $\begin{array}{l}62.99^{\mathrm{aC}} \\
\pm 2.98\end{array}$ & $\begin{array}{l}61.84^{\mathrm{bD}} \\
\pm 2.74\end{array}$ & $\begin{array}{l}61.47^{\mathrm{bD}} \\
\pm 2.56\end{array}$ & $\begin{array}{l}60.28^{\mathrm{cE}} \\
\pm 2.38\end{array}$ & $\begin{array}{l}37.01^{\mathrm{cF}} \\
\pm 2.25\end{array}$ & $\begin{array}{l}39.72^{\mathrm{aD}} \\
\pm 2.31\end{array}$ & $\begin{array}{l}38.16^{\mathrm{bE}} \\
\pm 2.28\end{array}$ & $\begin{array}{l}38.53^{\mathrm{bE}} \\
\pm 2.29\end{array}$ \\
\hline $\mathrm{T} 3$ & $\begin{array}{l}60.72^{\mathrm{aDE}} \\
\pm 2.44\end{array}$ & $\begin{array}{l}59.96^{\text {abF }} \\
\pm 2.15\end{array}$ & $\begin{array}{l}59.07^{\mathrm{bF}} \\
\pm 2.08\end{array}$ & $\begin{array}{l}58.07 \mathrm{~d}^{\mathrm{cG}} \\
\pm 2.05\end{array}$ & $\begin{array}{l}39.28^{\mathrm{dD}} \\
\pm 2.29\end{array}$ & $\begin{array}{l}40.05^{\mathrm{cC}} \\
\pm 2.33\end{array}$ & $\begin{array}{l}40.93^{\text {bB }} \\
\pm 2.32\end{array}$ & $\begin{array}{l}41.94^{\mathrm{aA}} \\
\pm 2.35\end{array}$ \\
\hline
\end{tabular}

Control - processed cheese sauce made without camel milk powder (CMP), T1 - 5\% CMP, T2 - 10\% CMP.

The means with the different small $(\mathrm{a}-\mathrm{c})$ superscript letters within the same row indicate significant $(P \leq 0.05)$ differences between treatments for storage period treatments.

Means with the different capital $(\mathrm{A}-\mathrm{G})$ superscript letters within the same column are significantly $(P \leq 0.05)$ different between storage period and concentrations of camel milk powder treatments.

the storage period of 10 to 30 days, the moisture decreased, and the total solids increased to record the lowest moisture and highest total solids at the end of the storage period. The increase in total solids with the increase in the substitution of cheddar cheese with camel milk powder may be due to the water holding capacity of camel milk powder that revealed the high concentration of whey protein in camel milk powder compared to other types of milk. The same finding was reported by Hailu et al. (2016).

The $\mathrm{pH}$ values of the processed cheese sauce with camel milk powder in different ratios when fresh and after 10, 20 and 30 days of storage at refrigerator temperature are presented in Table 3.

Table 3. $\mathrm{pH}$ values of processed cheese sauce manufactured using different ratios of camel milk powder fresh and during storage period

\begin{tabular}{ccccc}
\hline \multirow{2}{*}{$\begin{array}{c}\text { Storage period } \\
\text { days }\end{array}$} & \multicolumn{4}{c}{ Treatments / $\mathrm{pH}$ values } \\
\cline { 2 - 5 } Fresh & control & $\mathrm{T} 1$ & $\mathrm{~T} 2$ & $\mathrm{~T} 3$ \\
\hline 10 & $5.65^{\mathrm{cD}} \pm 0.51$ & $5.75^{\mathrm{bBC}} \pm 0.53$ & $5.79^{\mathrm{abAB}} \pm 0.60$ & $5.81^{\mathrm{aA}} \pm 0.63$ \\
20 & $5.63^{\mathrm{bDE}} \pm 0.50$ & $5.65^{\mathrm{abDE}} \pm 0.49$ & $5.70^{\mathrm{aC}} \pm 0.54$ & $5.68^{\mathrm{aCD}} \pm 0.52$ \\
30 & $5.53^{\mathrm{cFG}} \pm 0.49$ & $5.57^{\mathrm{bCEF}} \pm 0.46$ & $5.68^{\mathrm{aCD}} \pm 0.52$ & $5.61^{\mathrm{bE}} \pm 0.51$ \\
\hline
\end{tabular}

Control - processed cheese sauce made without camel milk powder (CMP), T1 - 5\% CMP, T2 - 10\% CMP, T3 - 15\% CMP.

The means with the different small $(\mathrm{a}-\mathrm{c})$ superscript letters within the same row indicate significant $(P \leq 0.05)$ differences between treatments for storage period treatments.

Means with the different capital $(\mathrm{A}-\mathrm{H})$ superscript letters within the same column are significantly $(P \leq 0.05)$ different between storage period and concentrations of camel milk powder treatments. 
Desouky, M. M., Salama, H. H., El-Sayed, S. M. (2019). The effects of camel milk powder on the stability and quality properties of processed cheese sauce. Acta Sci. Pol. Technol. Aliment., 18(4), 349-359. http://dx.doi.org/10.17306/J.AFS.2019.0645

Table 4. Meltability of processed cheese sauce manufactured using different ratios of camel milk powder fresh and during storage period

\begin{tabular}{ccccc}
\hline \multirow{2}{*}{$\begin{array}{c}\text { Storage period } \\
\text { days }\end{array}$} & \multicolumn{4}{c}{ Treatments / Meltability, mm } \\
\cline { 2 - 4 } & control & $\mathrm{T} 1$ & $\mathrm{~T} 2$ & $\mathrm{~T} 3$ \\
\hline Fresh & $11.4^{\mathrm{aFF}} \pm 0.72$ & $10.9^{\mathrm{aF}} \pm 0.66$ & $9.6^{\mathrm{bG}} \pm 0.63$ & $8.4^{\mathrm{cH}} \pm 0.60$ \\
10 & $12.2^{\mathrm{aC}} \pm 0.75$ & $11.6^{\mathrm{bDE}} \pm 0.69$ & $11.2^{\mathrm{bE}} \pm 0.70$ & $11.2^{\mathrm{bE}} \pm 0.68$ \\
20 & $13.4^{\mathrm{aB}} \pm 0.84$ & $12.6^{\mathrm{bBC}} \pm 0.73$ & $12.2^{\mathrm{bcC}} \pm 0.72$ & $11.8^{\mathrm{cD}} \pm 0.70$ \\
30 & $14.4^{\mathrm{aA}} \pm 0.86$ & $13.4^{\mathrm{bB}} \pm 0.81$ & $13.6^{\mathrm{bB}} \pm 0.85$ & $12.2^{\mathrm{cC}} \pm 0.71$ \\
\hline
\end{tabular}

Control - processed cheese sauce made without camel milk powder (CMP), T1 - 5\% CMP, T2 - 10\% CMP, T3 - $15 \%$ CMP.

The means with the different small $(\mathrm{a}-\mathrm{c})$ superscript letters within the same row indicate significant $(P \leq 0.05)$ differences between treatments for storage period treatments.

Means with the different capital $(\mathrm{A}-\mathrm{H})$ superscript letters within the same column are significantly $(P \leq 0.05)$ different between storage period and concentrations of camel milk powder treatments.

The $\mathrm{pH}$ values of the processed cheese sauce treatments were $5.65,5.75,5.79$ and 5.81 for the control and treatments with the camel milk powder, respectively. Results indicated that the control has a lower $\mathrm{pH}$ value than that of all other treatments. This could be due to the higher cheddar cheese ratio in the base blend. Treatments with camel milk powder generally showed higher $\mathrm{pH}$ values than the control. Among all treatments, processed cheese sauce with camel milk at a ratio of $15 \%$ has the highest $\mathrm{pH}$ value. During storage of the cheese sauce samples, the $\mathrm{pH}$ decreased with an extension in the storage period. The $\mathrm{pH}$ values in stored samples up to 30 days at $5 \pm 1{ }^{\circ} \mathrm{C}$ were 5.42 , $5.53,5.54$, and 5.49 for the control and cheddar cheese substituted with camel milk powder at $0 \%, 5 \%, 10 \%$ and $15 \%$ respectively. The changes in $\mathrm{pH}$ values during storage could be due to the changes occurring in emulsifying salt form, lactose content, and SN contents. The data are agreed with by Aly et al. (1995), Awad (2003) and Hassan et al. (2007).

The results presented in Table 4 refer to the meltability of the processed cheese sauces manufactured by different ratios of camel milk powder, fresh and during the storage period. They were recorded as cheese flow $[\mathrm{mm}]$. The processed cheese sauce exhibited meltability values of $10.9 \mathrm{~mm}, 9.6 \mathrm{~mm}$ and $8.4 \mathrm{~mm}$ at ratios of $5 \%, 10 \%$ and $15 \%$, respectively, compared to $11.4 \mathrm{~mm}$ for the control treatment. The results indicated that meltability values of the processed cheese sauce with camel milk powder decreased with an increase in the camel milk powder addition to the cheese base formula, which may be due to the moisture content, total solids, and high whey protein content in camel milk powder. The meltability of the processed cheese sauce during the storage period increased to its highest meltability after 30 days with the control treatment $(14.4 \mathrm{~mm})$. The data indicated that during storage the meltability values of the processed cheese sauce increased in all treatments, even the control. This might be due to the higher soluble nitrogen content of all treatments as confirmed by Hassan et al. (2007).

Table 5 shows the oil separation index of the cheese sauce treatments during the storage period. Fresh processed cheese sauce exhibited an oil index value of 0.148 for the control while it was $0.34,0.30$ and 0.034 for the treatments of camel milk powder in ratios of $5 \%, 10 \%$ and $15 \%$ respectively. The data showed that the processed cheese sauce with camel milk powder has relatively lower oil index values than the control. The fat separation decreased with an increase in the percentage of camel milk powder added to the blends.

The differences in oil separation values among the treatments are mainly due to the nature of the protein in the blend and/or the emulsification degree of the product. The protein in cheddar cheese (mainly casein) produced a network in the final product while the protein of camel milk powder would be better able to do the same as its high amount of whey protein (Hailu et al., 2016). With a higher ability to produce a network, the product became more emulsified, showing 
Desouky, M. M., Salama, H. H., El-Sayed, S. M. (2019). The effects of camel milk powder on the stability and quality properties of processed cheese sauce. Acta Sci. Pol. Technol. Aliment., 18(4), 349-359. http://dx.doi.org/10.17306/J.AFS.2019.0645

Table 5. Oil separation index of processed cheese sauce manufactured using different ratios of camel milk powder fresh and during storage period

\begin{tabular}{|c|c|c|c|c|}
\hline \multirow{2}{*}{$\begin{array}{l}\text { Storage period } \\
\text { days }\end{array}$} & \multicolumn{4}{|c|}{ Treatments / Oil separation index } \\
\hline & control & $\mathrm{T} 1$ & $\mathrm{~T} 2$ & $\mathrm{~T} 3$ \\
\hline Fresh & $0.148^{\mathrm{bD}} \pm 0.01$ & $0.34^{\mathrm{aB}} \pm 0.04$ & $0.30^{\mathrm{aB}} \pm 0.03$ & $0.034^{\mathrm{cE}} \pm 0.04$ \\
\hline 10 & $0.214^{\mathrm{bC}} \pm 0.03$ & $0.105^{\mathrm{cD}} \pm 0.008$ & $0.87^{\mathrm{aA}} \pm 0.06$ & $0.071^{\mathrm{dE}} \pm 0.001$ \\
\hline 20 & $0.231^{\mathrm{bC}} \pm 0.03$ & $0.138^{\mathrm{cD}} \pm 0.01$ & $0.112^{\mathrm{dD}} \pm 0.009$ & $0.84^{\mathrm{aA}} \pm 0.05$ \\
\hline 30 & $0.258^{\mathrm{aC}} \pm 0.04$ & $0.231^{\mathrm{aC}} \pm 0.02$ & $0.148^{\mathrm{bD}} \pm 0.01$ & $0.129^{\mathrm{bD}} \pm 0.01$ \\
\hline
\end{tabular}

Control - processed cheese sauce made without camel milk powder (CMP), T1 - 5\% CMP, T2 - 10\% CMP, T3 - $15 \%$ CMP.

The means with the different small $(\mathrm{a}-\mathrm{d})$ superscript letters within the same row indicate significant $(P \leq 0.05)$ differences between treatments for storage period treatments.

Means with the different capital (A-E) superscript letters within the same column are significantly $(P \leq 0.05)$ different between storage period and concentrations of camel milk powder treatments.

a lower oil separation index in the treatment compared with the control. Although the addition of camel milk powder to the formula leads to more casein networks, the cheese sauce was able to bind fat better than the control. This may be due to the fact that the camel milk powder contains high amounts of whey protein which have a stabilizing and emulsifying effect that may play a role in lowering the oil separation. The oil index of the processed cheese sauce in both the control and with camel milk powder was affected by the storage period. The free oil increased with an extension in the storage period. After 30 days of storage, the processed cheese samples had an oil separation index of 0.258 , $0.231,0.148$ and 0.129 for the control, $5 \%, 10 \%$ and $15 \%$ with the camel milk powder, respectively. The increase in oil separation in the stored processed samples could be correlated to the increase in soluble nitrogen contents (more decomposition of protein) which result in a lower degree of emulsification and higher fat leakage. These results are in accordance with the findings of Abd El-Hamid et al. (2000) and Awad (2003).

Differences in viscosity $[\mathrm{cP}]$ of all the processed cheese during storage are illustrated in Figure 1. It could be observed that increasing the ratio of CMP from $5 \%$ to $15 \%$ significantly $(p \leq 0.05)$ increased the viscosity. The flow behavior exposed that the viscosity values decreased in all treatments when the viscometer speed increased. Samples of cheese sauce T3 (15\% CMP), either fresh or during storage, were characterized by the highest viscosity values compared with all the other treatments and the control. This could be due to the nature of the camel milk protein added to the recipe, which plays the role of a colloidal and thickening agent that may help to bind more water than soluble material (Al-Shamsi et al., 2018). While a lower viscosity in the control could be due to the higher lactose and ash content as soluble matter (Noisuwan et al., 2008). Viscosity values $(p \leq 0.05)$ decreased during the storage period, which is due to the fact that viscosity is affected by several factors, such as $\mathrm{pH}$ values, state of the protein network and moisture content. The data agree with those of Awad et al. (2014).

Among treatments, the cheese sauce containing $15 \%$ CMP (T3) was characterized by higher viscosity values and showed a higher upward shift of the flow curve, as compared with the other treatments (Fig. 1D).

The sensory evaluation scores of the processed cheese sauce made using different ratios of camel milk powder during storage periods at $6 \pm 0.5^{\circ} \mathrm{C}$ for 30 days are presented in Table 6 .

All treatments were acceptable with significant differences $(p \leq 0.05)$ between them, where camel milk powder concentration and time of storage were the principal factors influencing the sensory properties. All treatments, as well as the control, had a good general appearance, body and texture and a pleasant creamy flavour. It is clear that no changes occurred in colour or appearance, either in fresh or in stored treatments. The data also indicated that the sensory 

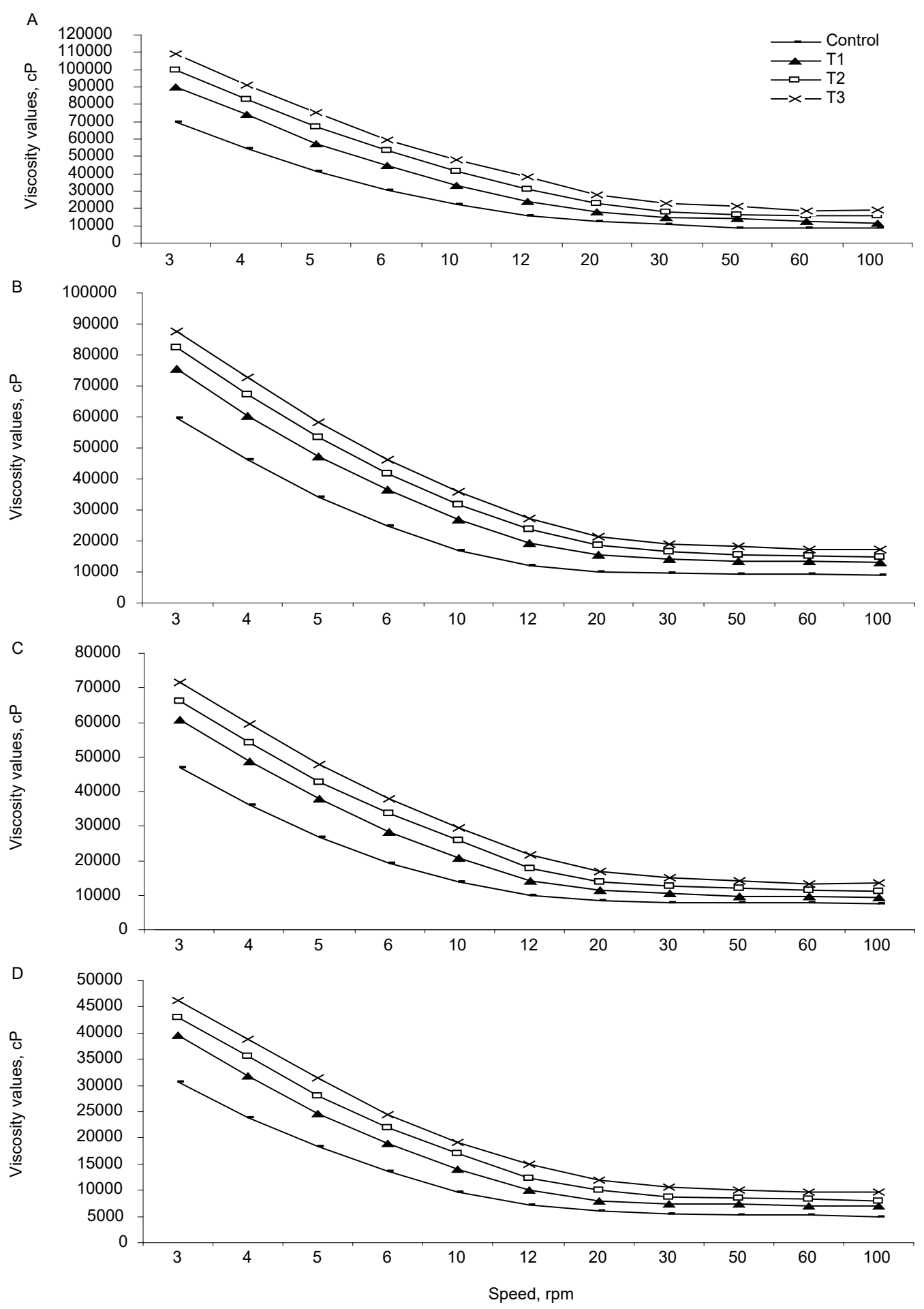

Fig. 1. Viscosity values $(\mathrm{cP})$ of processed cheese sauces manufactured using different camel milk powder when fresh (A), after 10 days (B), 20 days (C) and 30 days (D) of storage $6 \pm 0.5^{\circ} \mathrm{C}$ 
Desouky, M. M., Salama, H. H., El-Sayed, S. M. (2019). The effects of camel milk powder on the stability and quality properties of processed cheese sauce. Acta Sci. Pol. Technol. Aliment., 18(4), 349-359. http://dx.doi.org/10.17306/J.AFS.2019.0645

Table 6. Changes in sensory evaluation of processed cheese sauce manufactured using different ratios of camel milk powder during cold storage period

\begin{tabular}{|c|c|c|c|c|c|}
\hline \multirow{2}{*}{$\begin{array}{l}\text { Storage period } \\
\text { days }\end{array}$} & \multirow{2}{*}{$\begin{array}{l}\text { Character } \\
\text { assessed }\end{array}$} & \multicolumn{4}{|c|}{ Treatments } \\
\hline & & control & $\mathrm{T} 1$ & $\mathrm{~T} 2$ & $\mathrm{~T} 3$ \\
\hline \multirow[t]{4}{*}{ Fresh } & O.A (20) & $16^{\mathrm{cD}} \pm 1.34$ & $18^{\mathrm{bB}} \pm 1.65$ & $19.5^{\mathrm{aA}} \pm 1.82$ & $19^{\mathrm{aA}} \pm 1.76$ \\
\hline & B\&T (40) & $35^{\mathrm{dE}} \pm 2.14$ & $36^{\mathrm{cD}} \pm 2.24$ & $38^{\mathrm{bB}} \pm 2.28$ & $38.5^{\mathrm{aA}} \pm 2.30$ \\
\hline & $\mathrm{A} \& \mathrm{~F}(40)$ & $35^{\mathrm{dE}} \pm 2.17$ & $36^{\mathrm{cD}} \pm 2.21$ & $39^{\mathrm{bA}} \pm 2.33$ & $39.5^{\mathrm{aA}} \pm 2.31$ \\
\hline & total & $86^{\mathrm{dK}} \pm 3.89$ & $90^{\mathrm{cG}} \pm 4.07$ & $96.5^{\mathrm{bB}} \pm 4.11$ & $97^{\mathrm{aA}} \pm 4.12$ \\
\hline \multirow[t]{4}{*}{10} & O.A & $17^{\mathrm{bC}} \pm 1.64$ & $17^{\mathrm{bC}} \pm 1.68$ & $18^{\mathrm{aB}} \pm 1.75$ & $18^{\mathrm{aB}} \pm 1.80$ \\
\hline & $\mathrm{B} \& \mathrm{~T}$ & $33^{\mathrm{dG}} \pm 2.09$ & $35^{\mathrm{cE}} \pm 2.12$ & $36^{\mathrm{bD}} \pm 2.18$ & $38^{\mathrm{aB}} \pm 2.26$ \\
\hline & $A \& F$ & $35^{\mathrm{dE}} \pm 2.11$ & $37^{\mathrm{cC}} \pm 2.18$ & $38^{\mathrm{bB}} \pm 2.27$ & $39^{\mathrm{aA}} \pm 2.29$ \\
\hline & total & $85^{\mathrm{dL}} \pm 3.74$ & $89^{\mathrm{cH}} \pm 3.76$ & $92^{\mathrm{bE}} \pm 4.09$ & $95^{\mathrm{aC}} \pm 4.10$ \\
\hline \multirow[t]{4}{*}{20} & O.A & $16^{\mathrm{cD}} \pm 1.28$ & $17^{\mathrm{bC}} \pm 1.34$ & $17^{\mathrm{bC}} \pm 1.31$ & $18^{\mathrm{aB}} \pm 1.45$ \\
\hline & $\mathrm{B} \& \mathrm{~T}$ & $32^{\mathrm{dH}} \pm 1.92$ & $34^{\mathrm{cF}} \pm 2.15$ & $37^{\mathrm{bC}} \pm 2.24$ & $38^{\mathrm{aB}} \pm 2.26$ \\
\hline & $A \& F$ & $34^{\mathrm{dF}} \pm 2.09$ & $36^{\mathrm{cD}} \pm 2.21$ & $37^{\mathrm{bC}} \pm 2.23$ & $38^{\mathrm{aB}} \pm 2.27$ \\
\hline & total & $82^{\mathrm{dM}} \pm 3.54$ & $87^{\mathrm{cJ}} \pm 3.71$ & $91^{\mathrm{bF}} \pm 3.85$ & $94^{\mathrm{aD}} \pm 4.08$ \\
\hline \multirow[t]{4}{*}{30} & O.A & $15^{\mathrm{bE}} \pm 1.20$ & $16^{\mathrm{aD}} \pm 1.25$ & $16^{\mathrm{aD}} \pm 1.26$ & $16^{\mathrm{aD}} \pm 1.28$ \\
\hline & $\mathrm{B} \& \mathrm{~T}$ & $31^{\mathrm{cI}} \pm 1.85$ & $35^{\mathrm{bE}} \pm 2.13$ & $36^{\mathrm{aD}} \pm 2.16$ & $36^{\mathrm{aD}} \pm 2.17$ \\
\hline & $A \& F$ & $33^{\mathrm{dG}} \pm 2.06$ & $35^{\mathrm{cE}} \pm 2.10$ & $35 \mathrm{bE} \pm 2.12$ & $36^{\mathrm{aD}} \pm 2.18$ \\
\hline & total & $79^{\mathrm{dN}} \pm 3.41$ & $86^{\mathrm{cK}} \pm 3.52$ & $87^{\mathrm{bJ}} \pm 3.56$ & $88^{\mathrm{aI}} \pm 3.61$ \\
\hline
\end{tabular}

Control - processed cheese sauce made without camel milk powder (CMP), T1 - 5\% CMP, T2 - 10\% CMP, T3 - 15\% CMP. O.A - outer appearance, B\&T - body \& texture, A\&F - aroma \& flavor.

The means with the different small $(\mathrm{a}-\mathrm{d})$ superscript letters within the same row indicate significant $(P \leq 0.05)$ differences between treatments for storage period treatments.

Means with the different capital (A-E) superscript letters within the same column are significantly $(P \leq 0.05)$ different between storage period and concentrations of camel milk powder treatments.

quality attributes of all the processed cheese sauce treatments, including the control, slightly decreased with an extension in the storage period. These dates agree with the findings of Awad et al. (2014). Also, the body and texture of the cheese sauce improved and the cheese was easier to slice with an increase in the ratio of camel milk powder in the blend. The highest values camel milk powder were in the $\mathrm{T} 3$ treatments, which were very smooth, more homogenous and less viscous than the other treatments, including the control, either fresh or throughout the storage periods. This may be due to the fact that the camel milk powder contains high amounts of whey proteins which have stabilizing and emulsifying properties that may play a role in improving texture properties, Al-Shamsi et al. (2018). As is shown by the scores listed in Table 6 , the flavour of processed cheese sauce becomes more preferable with an increase in the camel milk powder in the blend up to $10 \%$ compared to the control. These scores proved that sauces with $15 \%$ camel milk powder possessed the highest scores and were the most bright and shiny compared with all the other sauces. Meanwhile, the control scored the lowest points for outer appearance, exhibited a less viscous, thinner body and was less preferable to the panelists. Aroma and flavour scores of the processed cheese sauces were highly affected 
$(p \leq 0.05)$ by the ratio of camel milk powder in the blends. The aroma and flavour were acceptable in all formulas being the least in the control and the best in T3. Increasing the ratio of camel milk powder in processed cheese blends could be recommended up to $10 \%$ and the final products displayed the highest chemical, physical and sensory properties during the storage period.

\section{REFERENCES}

Abd El-Hamid, L. B., El-Shabrawy, S. A., Awad, R. A., Singh, R. K. (2000). Rheology and microstructure of processed Ras cheese spreads with formulated emulsifing salt mixture. Int. J. Food Prop., 3, (1), 59-75. https://doi. org/10.1080/10942910009524616

Al-Shamsi, K. A., Mudgil, P., Hassan, H. M., Maqsood, S. (2018). Camel milk protein hydrolysates with improved techno functional properties and enhanced antioxidant potential in vitro and in food model systems. J. Dairy Sci., 101(1), 47-60. https://doi.org/10.3168/ jds.2017-13194

Aly, M. E., Abdel-Baky, A. A., Farahat, S. M., Hana, U. U. B. (1995). Quality of processed cheese spread made using ultrafiltrated retentates with some ripening agents. Int. Dairy J., 5,(2), 191-209. https://doi. org/10.1016/0958-6946(95)92210-U

AOAC (2007). Official Methods of Analysis. $17^{\text {th }}$ ed., Gaithersburg, MD, USA: Association of Official Analytical Chemists.

Awad, R. A. (2003). Impact of potato puree as a cheese base replacement in the manufacture of processed cheese. Egypt. J. Dairy Sci., 31(2), 375-387. https://www.food. actapol.net/pub/5_1_2014

Awad, R. A., Wafaa, M. S., Azza, M. F. (2014). Effect of lupine as cheese base substitution on technological and nutritional properties of processed cheese analogue. Acta Sci. Pol. Technol. Aliment., 13(1), 55-64.

Childs, J. L., Yates, M. D., Drake, M. A. (2009). Sensory properties and consumer perception of wet and dry cheese sauces. J. Food Sci., 74, 6, S205-S218. https:// doi.org/10.1111/j.1750-3841.2009.01187.x

Gul, W., Farooq, N., Anees, D., Khan, U., Rehan, F. (2015). Camel milk: A boon to mankind. Int. J. Res. Stud. Biosci. (IJRSB) 3(11), 23-29. https://bengreenfieldfitness.com/wp-content/uploads/2017/02/ Camel-Milk-A-Boon-to-Mankind

Hailu, Y., Hansen, E. B., Seifu, E., Eshetu, M., Ipsen, R., Kappeler, S. (2016). Functional and technological properties of camel milk proteins: a review. J. Dairy Res., 83(4), 422-429. https://doi.org/10.1017/S0022029916000686

Hashim, B., Khalil, A. H., Habib, H. (2009). Quality and acceptability of a set-type yogurt made from camel milk. J. Dairy Sci., 92(3), 857-862. https://doi.org/10.3168/ jds.2008-1408

Hassan, Z. M. R., Hammad, Y., Hassanin, A. M., Salama, H. (2007). Utilization of soy bean flour and flaxseed flake in the manufacture of processed cheese spread. In Egyptian Conference for Dairy Science and Technology, Research Papers, held at The International Agriculture Centre Cairo, Egypt. 19-21 November (pp. 463-479).

Kappeler, S. R., Van den Brink, H. J., Rahbek-Nielsen, H., Farah, Z., Puhan, Z., Hansen, E. B., Johansen, E. (2016). Characterization of recombinant camel chymosin reveals superior properties for the coagulation of bovine and camel milk. Biochem. Biophys. Res. Comm., 342, 647-654. http://dx.doi.org/10.1016/j.bbrc.2006.02.014

Kim, E. H. J., Chen, X., Pearce, D. (2005). Effect of surface composition on the flowability of industrial spray-dried dairy powders. Colloid. Surface B, 46(3), 182-187. http://dx.doi.org/10.1016/j.colsurfb.2005.11.005

Kim, E. H. J., Chen, X., Pearce, D. (2008). Surface composition of industrial spray dried dairy powders. 1. Development of surface composition during manufacture. J. Food Eng., 94(2), 193-198. https://doi.org/10.1016/j. jfoodeng.2008.09.021

Korashy, H. M., Maayah, Z. H., Abd-Allah, A. R., El-Kadi, A. O. S., Alheider, A. A. (2012). Camel milk triggers apoptotic signaling pathways in human hepatoma HepG2 and breast cancer MCF7 cell lines through transcriptional mechanism. J. Biomed. Biotechnol., 1-9. http:// dx.doi.org/10.1155/2012/593195

Li, L., Singh, R. K., Jun, H. O., Lee, J. H. (2004). Process conditions influence on characteristics of holding tube fouling due to cheese sauce. Lebensm. Wiss. Technol., 37, 565-572. https://doi.org/10.1016/j.lwt.2004.01.002

Ling, E. R. (1963). A text book of dairy chemistry ( $3^{\text {rd }}$ ed., vol. 2., pp. 76-98). London, UK: Chapman and Hall.

Meyer, A. (1973). Processed cheese manufacture ( $1^{\text {st }}$ ed.). London, UK: Food Trade Press.

Mohamed, A. G., Abbas, H. M., Bayoumi, H. M., Kassem, J. M., Enab, A. K. (2011). Processed cheese spreads fortified with oat. J. Am. Sci., 7, 631-637.

Moslehishad, M., Ehsani, M. R., Salami, M., Mirdamadi, S., Ezzatpanah, H., Naslaji, A. N., Moosavi-Movahedi, A. A. (2013). The comparative assessment of ACE-inhibitory and antioxidant activities of peptide fractions obtained from fermented camel and bovine milk by Lactobacillus 
Desouky, M. M., Salama, H. H., El-Sayed, S. M. (2019). The effects of camel milk powder on the stability and quality properties of processed cheese sauce. Acta Sci. Pol. Technol. Aliment., 18(4), 349-359. http://dx.doi.org/10.17306/J.AFS.2019.0645

rhamnosus PTCC 1637. Int. Dairy J., 29(2), 82-87. https://doi.org/10.1016/j.idairyj.2012.10.015

Mujumdar, A. S. (2007). Handbook of industrial drying ( $3^{\text {rd }}$ ed.). Boca Raton, FL: CRC Press. https://doi. org/10.1080/07373930701399224

Noisuwan, A., Bronlund, J., Wilkinson, B., Hemar, Y. (2008). Effect of milk protein products on the rheological and thermal (DSC) properties of normal rice starch and waxy rice starch. Food Hydrocoll., 22, 174-183. https://doi.org/10.1016/j.foodhyd.2007.01.009

Olson, N. F., Price, W. V. (1958). A melting test for pasteurized process cheese spreads. J. Dairy Sci., 41(4), 991-999.

Quan, S., Tsuda, H., Miyamoto, T. (2008). Angiotensin I-converting enzyme inhibitory peptides in skim milk fermented with Lactobacillus helveticus 130B4 from camel milk in Inner Mongolia, China. J. Sci. Food Agric., 88(15), 2688-2692. https://doi.org/10.1002/jsfa.3394

Savello, P. A., Ernstrom, C. A., Kalab, M. (1989). Microstructure and meltability of model process cheese made with rennet and acid casein. J. Dairy Sci., 72(1), 1-11. https://doi.org/10.3168/jds.S0022-0302(89)79073-1

Sharma, C., Singh, C. (2014). Therapeutic value of camel milkA review. Adv. J. Pharm. Life Sci. Res., 3(2), 7-13. http:// ajplronline.org/uploadfile/635464294846827709.pdf

Solowiej, B., Mleko, S., Gustaw, W., Udeh, K. O. (2010). Effect of whey protein concentrates on texture, meltability and microstructure of acid casein processed cheese analogs. Milchwissenschaft, 65(2), 169-173.

SPSS (2007). Statistical package for social science. Chicago, IL, USA: SPSS.

Thomas, M. A. (1973). The use of a hard milk fat fraction in processed cheese. Aust. J. Dairy Technol., 28(1), 77-80.

Thomas, M. E. C., Scher, J., Desobry, S. (2004). Milk powder ageing: effect on physical and functional properties. Crit. Rev. Food Sci. Nutr., 44(5), 297-322.

Viturawong, Y., Achayuthakan, P., Suphantharika, M. (2008). Gelatinization and rheological properties of rice starch/xanthan mixtures: Effects of molecular weight of xanthan and different salts. Food Chem., 111(1), 106114. http://dx.doi.org/10.1016/j.foodchem.2008.03.041 